\title{
Business Sustainability in the Pandemic Covid 19: Study at MSMES in Jambi City
}

\author{
Ilham Wahyudi ${ }^{1}$, ${ }^{\text {Wiwik Tiswiyanti }}{ }^{2}$, Sosiawan Nusifera $^{3}$ \\ ${ }^{123}$ Ecomomics and Busness Faculty, Universitas Jambi \\ Jalan Raya Jambi-Muara Bulian Km 15, Muaro Jambi, Jambi, Indonesia \\ *Corresponding author Email: Ilham_wahyudi@unja.ac.id
}

\begin{abstract}
The Covid-19 pandemic impacted various sectors, including Micro, Small, and Medium Enterprises (MSMEs). The research aims to: 1) Analyze the level of sustainability of MSMEs in Jambi City 2) Efforts that can make so that MSMEs can survive and have a competitive advantage; 3) Provide a theoretical basis for the government in formulating policies to develop MSMEs in Indonesia. The research method is quantitative and qualitative, using primary data with a sample size of 66 MSMEs in Jambi City. The data were analyzed using Partial Least Square (PLS) to obtain a strategy model for MSME business sustainability. The results showed that improvements did not influence the sustainability level of MSMEs in internal processes. Furthermore, internal process improvement not affects the profile of MSMEs and external environmental support.
\end{abstract}

Keywords: Covid 19, MSMEs, Business sustainability.

\section{INTRODUCTION}

MSMEs provide a significant enough contribution to GDP. MSMEs use to support the economy and continue to grow positively in the face of the global environment.

The covid 19 outbreak, which the government announced in March 2020, has put Indonesia's global and domestic economy under pressure. Based on the Bank Indonesia Monetary Policy Report for the first quarter of the year, the Indonesian economy only grew by $2.97 \%$ (YoY), slowing down from the previous quarter's growth of $4.97 \%$ (YoY). The decline stemmed from the slowdown in service exports (tourism, non-food consumption, investment, hotels, and restaurants (PHR), the manufacturing sector, the construction sector, and the transportation subsect (Bank Indonesia, 2020).

The government is aware of the impact of Covid 19 by issuing a Government Regulation instead of Law No. 1 of 2020 (PERPPU 1/2020).; PMK-23/2020 and PMK 28/2020 discuss fiscal incentives to deal with the Covid-19 pandemic. The government is also committed to safeguarding the domestic industry the Covid-19 pandemic; by issuing PMK-30/2020, the government has imposed a postponement of excise payments to logistical constraints in the field due to Covid-19.
Jambi City MSMEs totaled 8,081 MSMEs (not including street vendors' MSMEs). The Jambi City Industry and Trade Office estimates that if the Covid 19 pandemic is prolonged, it will threaten MSME businesses' sustainability.

Business continuity (going concern) seen from financial science with indicators of profitability, liquidity, solvency shows good and positive numbers [1]. According to Kaplan \& Norton [2], the performance measurement theory introduces as a balanced scorecard.

Business continuity can see from various financial perspectives (financial perspective). Three (3) attitudes, namely customer satisfaction, internal business processes (continuous improvement), and learning and growth. Business sustainability will create when the business entity provides what is needed and customer satisfaction. For customer satisfaction to fulfill, business entities must provide a competitive advantage by always carrying out a learning and growth process to innovate and process continuous improvement for the better.

In the perspective of learning and growth, MSMEs must constantly improve employee skills through three dimensions, namely (1) Increasing individual abilities, (2) Increasing information system capabilities, and (3) 
Increasing personal motivation. The learning and growth perspective will encourage MSMEs to make continuous improvements, including process quality and process cycle times. The philosophy focuses on three main business processes, namely: the innovation process, the operation process, the post-sales process [3].

Penelitian (Yanti, Amanah, Muldjono, \& Asngari, 2018) menunjukkan tingkat keberlanjutan UMKM pada wilayah perkotaan lebih tinggi dibandingkan pada wilayah kabupaten. Hal ini ditunjukkan pada kualitas produk, serta inovasi yang lebih baik ditunjukkan pada wilayah Kota dibandingkan Kabupaten.

Faktor-faktor yang berpengaruh pada keberlanjutan usaha adalah factor persepsi pelaku UMKM dan faktor pemanfaatan sarana Tehnologi Informasi secara langsung. Survei Asia Foundationtahun 2001 di wilayah Bogor menunjukkanhanya, 18\% UMKM menggunakan situsecommerce. Akibatnya UMKM sangat terbatas jangkauan pemasaran produknya. UMKM diharap tetap tumbuh dan memopang perekonomian baik dalam keadaan krisis dan moneter seperti tahun yang lalu maupun dimasa pandemi covid-19. Penelitian bertujuan untuk melihat bagaiman tingkat keberlanjutan UMKM dan faktor-faktor dapt mendorong keberlanjutan UMKM di Kota Jambi.

\section{RESEARCH METHOD}

This research is a quantitative and qualitative type of research where primary data are analyzed. The data collection method is through distributing questionnaires to respondents to obtain facts and factual information from respondents. The study population was all MSMEs in Jambi City. The sample collection technique is determined randomly with ratified or disproportioned stratified random sampling. Determination of the number of samples using the Slovin formula and as many as 150 MSME entrepreneurs use as samples. Data analysis in research using the Partial Least Square (PLS) method.

\section{RESULT AND DISCUSSION}

\subsection{Descriptive Analysis}

The study's latent variables consisted of MSME profile, external environmental support, internal process improvement, and MSME sustainability. The MSME profile measure by three manifest indicators, namely education, total asset ownership, and motivation. For latent variables, external environmental support also measures by three manifest indicators: partner support, empowerment support, and access to information technology. Four manifest hands are internal process improvement for latent variables, namely individual components, technical components, product quality, and service quality. While the latent variable for the sustainability of MSMEs measure by four manifest indicators: profitability, asset growth, competitiveness, and marketing network.

The MSME profile has a relatively good average score of 2.63. The indicator that contributes to the increase in MSMEs' faces was the number of ownership with an average score of 3.90 or a reasonable scale. Meanwhile, the hand that most contributed to the decline in MSMEs' profile was a low motivation, with an average score of 1.30. That shows that MSMEs' capital structure is still predominantly sourced from the owner's capital and has not yet optimized the source of funds for creditors. Meanwhile, the motivation of MSME owners to innovate and expand is still shallow. Education is on a reasonably good scale, namely an average score of 2.68, and this is a good foundation for increasing the profile of MSMEs in Jambi City.

External support for MSME businesses is on a reasonably good scale, with an average score of 2.31 . Partner support has an average score of 2.27, empowerment support has an average score of 2.40, and access to information technology has an average score of 2.34 which means that all indicators are on a reasonably good scale. That shows that external support for MSME businesses is still not optimal. External environmental support is an important variable to continue to be improved to support a sustainable business.

Internal process improvement variable has a good average score, which is 4.18 . The product quality indicator contributed the most, namely 4.43 , which indicated that MSMEs carried on excellent process improvements by improving their quality. Likewise, the technical component indicator with an average score of 4.15 and the emotional component with an average score of 4.25 contributed to increased internal business processes improvement. However, there is still a need to improve the quality of service at MSMEs, where the average score is 3.89.

The MSME sustainability variable shows a good average score of 3.76. That indicates that fundamentally when the Covid19 pandemic has not yet hit Jambi City, indicators of profitability, asset growth, competitiveness, and MSME marketing networks in Jambi City are on a reasonably good scale. A severe problem related to the sustainability of the MSME business is the competitiveness of MSMEs and the marketing network, which still needs to be improved, especially in dealing with global trade issues and the industrial revolution 4.0. 
The data shows that the average sales volume of MSMEs in various sectors in Jambi City has decreased sales turnover by $30.2 \%$. That is the impact of the government's social restriction policies aimed at suppressing the coronavirus's spread. The COVID-19 pandemic has changed people's consumption behavior, and MSMEs are not ready to quickly anticipate these changes.

\subsection{Hypothesis Testing}

The indicator of a variable is said to have good reliability if the output loading value is above 0.7 [4]. Based on the table, extreme loading values are only a few variables greater than 0.7. based on the data, the research variables have met the requirements of concurrent validity testing.

Reliability testing does by looking at the Cronbach alpha value and the reliability of the composite. The variable is reliable if the composite reliability value is more significant than 0.7 and the Cronbach alpha value is greater than 0.7 [4]. Alpha Cronbach's importance in the external environmental support variable is more significant than 0.7 . Likewise, the value of the composite reliability variable is more significant than 0.7 . That means that only the research variables meet the reliability requirements of the examiners.

\subsection{Structural Model Testing}

A structural model is a model that connects latent variables exogenous with endogenous variables or endogenous relationship variables with other endogenous variables.

The coefficient of determination (R2) shows that the profile of MSMEs and external environmental support influences internal processes' improvement by $10.1 \%$. Furthermore, the progress of internal processes has an impact on the sustainability of MSMEs by $17.3 \%$.

The effect of the MSME profile on improving internal processes can see from the t-statistic value of 0.291 , which compare with the t-critical value of 1.96. Because the $\mathrm{t}$ statistic value is smaller than the t-critical value, with a $5 \%$ error rate, it can conclude that $\mathrm{H} 1$ rejects. This study proves that the improvement of internal processes is not related to the MSME profile.

The effect of internal environmental support on internal process improvement can see from the t-statistic value of 1.565 , which compares with the t-critical value of 1.96 . The $\mathrm{t}$-statistic value is smaller than the t-critical value. Thus it can conclude that at the $5 \%$ error level, $\mathrm{H} 2$ rejects. The research results prove that the improvement of internal processes is not related to external environmental support.

Internal process improvement on MSMEs' sustainability compared to the t-statistic value with the tcritical value. Based on the table above, the t-statistic value of 0.873 is greater than the $t$-critical value of 1.96 . Thus it can conclude that at an error rate of $5 \%, \mathrm{H} 3$ rejects. The research results prove that the business continuity of MSMEs is not related to internal process improvement.

\section{DISCUSSION}

\subsection{The Influence of MSME Profiles on the improvement of internal processes}

The test results found that the MSME profile did not affect improving internal processes. It can interpret that the improvement of internal processes cannot determine the level of education, the amount of ownership, and the MSME actors' motivation.

\subsection{The influence of external environmental support on internal process improvement}

The test results found that external environmental support did not affect improving MSMEs' internal processes. Thus, it can interpret that the improvement of MSMEs' internal processes cannot determine partner support, empowerment support, and access to information technology.

\subsection{Influence of internal process improvements on the sustainability of MSMEs}

The test results find that the improvement of internal processes does not affect MSMEs' sustainability. Thus, it can interpret that the progress of MSMEs' sustainability level cannot determine from the individual components, technical components, product quality, and service quality.

\subsection{MSME Sustainability Structural Model.}

Based on the test results in this study, a research model develops to maintain MSMEs' sustainability. The model developed is based on the MSME business's sustainability that can keep if MSMEs carry out continuous improvements to their internal processes. Efforts to improve the constant internal process will significantly influence MSMEs' internal factors and support from the MSME external environment.

The model developed has gone through selecting items on the research variable indicators that have the highest loading value. So that it best reflects the hands-on research variables. However, item loading on each hand that has not shown the most elevated value provides a research model that shows research results that do not strongly influence variables. 
Model yang direkomendasikan untuk

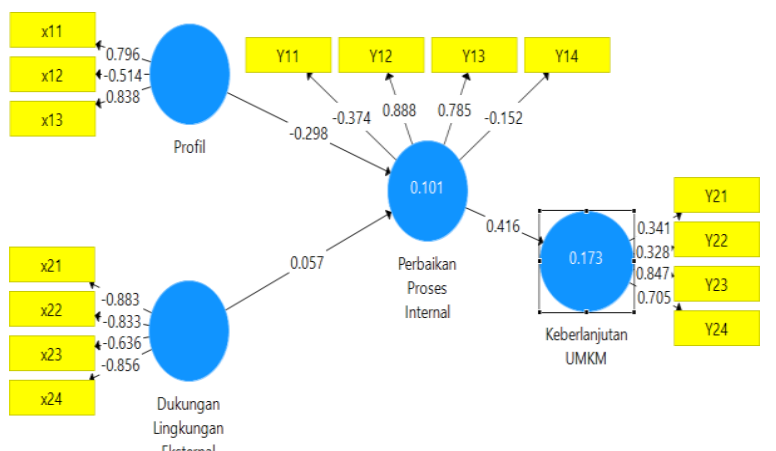

\section{CONCLUSION}

Based on the research results, the following conclusions can draw:

1. The MSME profile does not affect internal process improvement. That means that the progress of internal processes does not drive by an increase in MSMEs' faces.

2. External environmental support does not affect internal process improvement, which means that internal process improvement does not drive increased external ecological support.

3. Improvements in internal processes do not affect the sustainability of MSMEs. That means that increased internal process improvements do not drive MSME business sustainability.

\section{SUGGESTION}

Based on the research results and conclusions in this study, it is advisable to review the incentive policies for MSMEs issued since the Covid19 pandemic, such as tax incentives and bank credit relief. Future researchers expect to develop a model by adding other variables that can improve the sustainability of the MSME business.

\section{REFERENCES}

[1] R. B. Allen, S. Myers, \& Franklin. (2020). Principles of Corporate Finance, 13th edition. United States: McGraw-Hill.

[2] R. S. Kaplan, \& D. P. Norton. (1992). The Balanced Scorecard - Measures that drive performance. Harvard Business Review, 71-79.

[3] R. S. Kaplan, \& D. P. Norton. (1996). Linking Balanced Scorecard to Strategy. Harvard Business, 3949.

[4] J. Sarwono, \& U. Narimawati. (2015). Membuat Skripsi, Tesis dan Disertasi dengan Partial Least Square SEM (PLS-SEM). Yogyakarta: ANDI. 